\title{
Купірування кровотечі у пацієнтів з інгібіторною формою гемофілії
}

\section{Є.В. Авер'янов}

Державна установа «Інститут гематології та трансфузіології НАМН України», Київ, Україна

Інгібіторна форма гемофілії (ІФГ) - одне з найсерйозніших ускладнень гемофілії, що не дозволяє проводити адекватну факторзамісну терапію $[1,2]$. Внаслідок труднощів контролю епізодів кровотечі у пацієнтів з інгібіторами наявний підвищений ризик розвитку серйозних кровотеч, включно з гемартрозами. Наявні дані свідчать, що у пацієнтів з ІФГ існує:

- ризик прогресуючого захворювання суглобів, що призводить до інвалідності [3, 4];

- ризик погіршення якості життя, зумовленого станом здоров'я [5];

- потреба у пристроях, що полегшують мобільність, і ортопедичній хірургії [6].

Гемофілія характеризується гематомним типом кровоточивості, основним її клінічним проявом $€$ кровотечі та крововиливи, що виникають спонтанно чи внаслідок травм, а ступінь їх тяжкості корелює зі ступенем тяжкості самого захворювання. Одним $з$ основних та найбільш характерних клінічних симптомів гемофілії $\epsilon$ гемартрози - крововиливи у великі суглоби (гомілковостопні, колінні, кульшові, плечові, ліктьові). За даними різних авторів, до гемартрозу схильні до 95-100\% пацієнтів із тяжкою формою гемофілії А у разі відсутності профілактичного лікування. При цьому патологічні процеси, зокрема гіпертрофія синовіальної оболонки, її гіперваскуляризація та дегенерація хряща, які виникають внаслідок крововиливу в суглоб, у подальшому призводять до специфічного ураження суглобів - гемофілічної артропатії (ГА), яка $\epsilon$ основною причиною інвалідизації дітей ще до досягнення повноліття, а в деяких випадках - і в дошкільному віці. Так, результати дослідження щодо оцінки функціональної спроможності кінцівок у пацієнтів із ГА продемонстрували, що крововиливи у суглоби асоційовані з наявністю у хворих відносного укорочення верхніх та ниж- ніх кінцівок, дефіциту об'єму рухів у ліктьових суглобах на 36\%, колінних $-38 \%$, гомілковостопних $-10 \%$, що суттєво обмежує самообслуговування, сприяє швидкому виснаженню під час фізичного навантаження та значно погіршує якість життя пацієнтів [7].

Крововилив у суглоб негативно впливає на всі механізми обміну речовин, як у самому суглобі, так і в навколосуглобових структурах. Пусковим моментом, який призводить до розвитку ГА, $\epsilon$ виділення в синовіальну рідину заліза з гемоглобіну крові, що запускає реакції оксидативного стресу в суглобовій порожнині та у хрящі (рис. 1). Після крововиливу в суглоб гемосидерин, який $є$ продуктом розпаду гемоглобіну, поглинається макрофагами і відкладається у тканині синовіальної оболонки, що призводить до розвитку хронічного запального процесу в суглобі. Запалення, у свою чергу, призводить до виділення прозапальних цитокінів медіаторів запалення, включно 3 iнтерлейкінами (ІЛ), фактором некрозу пухлини (TNF)-a, які спричиняють гіпертрофію синовіальної оболонки та їі гіперваскуляризацію. Далі настає другий етап патогенезу гемартрозу, що характеризується змінами метаболізму синовіальної оболонки. У подальшому ГА трансформується у хронічний процес, який у результаті призводить до повної руйнації суглоба. У подальшому ГА трансформується у хронічний процес, який призводить до повної руйнації суглоба. Таким чином, у патофізіології розвитку ГА ключову роль відіграють такі ланки патогенезу, як гіпертрофія синовіальної оболонки, ії̈ гіперваскуляризація та дегенерація хряща, що в подальшому трансформується у хронічний процес, який у результаті призводить до повної руйнації суглоба (рис. 2).

Сьогодні єдиним патогенетично обґрунтованим методом лікування у разі гемофілічних кровотеч $€$ повноцінна гемостатична терапія, сучасна стратегія якої представлена трьома варіантами:

\section{Рисунок 1 Патогенез ГА [8]}

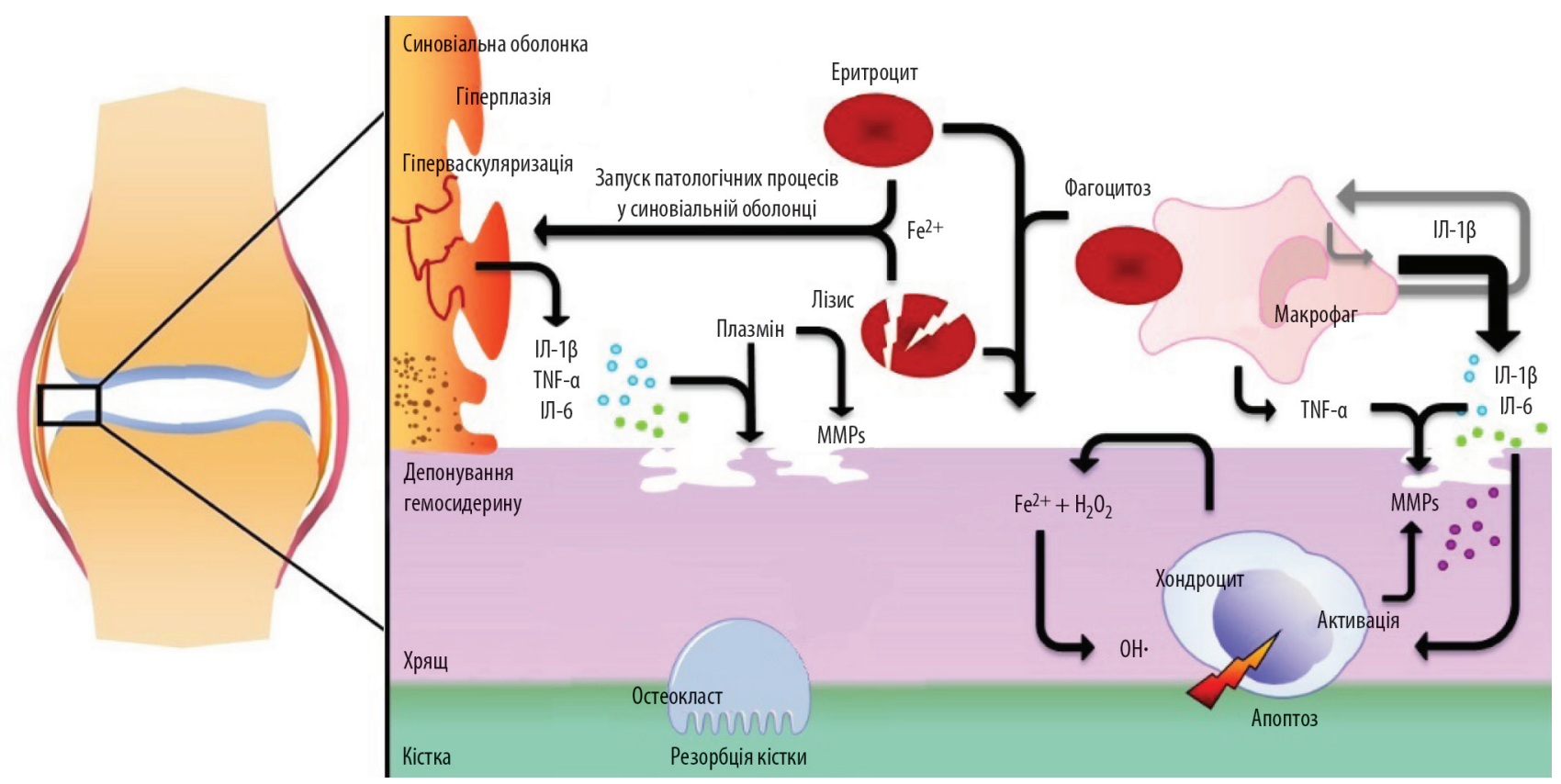


Рисунок 2 Патогенез ураження опорно-рухового апарату при гемофілії

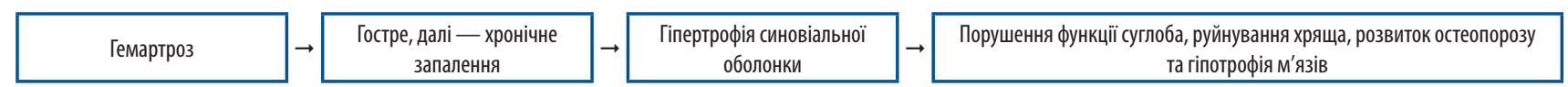

Рисунок 3 Стратегія гемостатичної інфузійної терапії у разі гострої кровотечі у пацієнтів із ІФГ

\begin{tabular}{|c|c|c|c|c|}
\hline$\geq 5$ БО/мл & $\rightarrow$ & $\begin{array}{c}\text { Препарати } \\
\text { шунтуючої дії }\end{array}$ & & $\begin{array}{l}\text { аРСС } \\
\text { або } \\
\text { ептаког альфа (активований) }\end{array}$ \\
\hline$<5$ Б0/мл & $\rightarrow$ & $\begin{array}{c}\text { Препарат фактора VIII у високій дозі } \\
\text { (стандартна доза х 3) }\end{array}$ & $\rightarrow$ & Препарати шунтуючої дії \\
\hline
\end{tabular}

Дозування препаратів із шунтуючим механізмом дії для зупинки кровотечі:

- аРСС призначають у дозі 50-100 М0/кг маси тіла кожні 12 год.

Максимальна добова доза — 200 М0/кг;

- ептаког альфа (активований) призначають у дозі 90-120 мкг/кг кожні 2-4 год до зупинки кровотечі. Можливе одноразове введення у дозі 270 мкг/кг/добу.
- замісна факторна гемостатична терапія;

- застосування препаратів із шунтуючим механізмом дії;

- нефакторна терапія (еміцизумаб).

Основною метою терапії у пацієнтів із гемофілією $\epsilon$ усунення епізодів кровотеч та запобігання їх рецидивам. Однак у пацієнтів з ІФГ стандартна терапія препаратами фактора згортання $\epsilon$ неефективною, що потребує пошуку альтернативних варіантів купірування кровотеч. Крім того, вибір препарату для лікування у разі кровотечі повинен ґрунтуватися на титрі інгібітора, відповіді на терапію та характері кровотечі (таблиця). Відповідно до сучасних рекомендацій, стратегія гемостатичної інфузійної терапії у разі гострої кровотечі у пацієнтів із ІФГ полягає у застосуванні препаратів з обхідним (шунтуючим) механізмом дії, таким як антиінгібіторний коагуляційний комплекс (аРСС) або рекомбінантний активований FVII (rFVIla) (рис. 3).

Таблиця Тактика лікування у разі кровотечі у пацієнтів з ІФГ

\begin{tabular}{|c|c|}
\hline \multicolumn{2}{|c|}{ Тактика лікування у разі кровотечі залежно від титру інгібітора } \\
\hline $\begin{array}{c}\text { Низький/низькореагуючий титр } \\
\text { інгібітора ( } \leq 5 \text { Б0/мл) }\end{array}$ & $\begin{array}{l}\text { Високий/високореагуючий титр інгібітора } \\
\text { (>5 Б0/мл) }\end{array}$ \\
\hline $\begin{array}{l}\text { - Препарат шунтуючої дії } \\
\text { - Фактор коагуляції у високій дозі } \\
\text { • Антифібринолітичний препарат } \\
\text { (транексамова кислота) } \\
\text { - Артроцентез } \\
\text { - Р.R.І.С.Е.* } \\
\text { - Фізіотерапія, реабілітація }\end{array}$ & $\begin{array}{l}\text { - Максимально ранній початок терапії } \\
\text { - Вибір шунтуючого препарату } \\
\text { - У разі ефективного лікування рекомендовано } \\
\text { продовжити терапію, редукуючи дозу } \\
\text { - У разі неефективності - зміна препарату } \\
\text { - Антифібринолітичний препарат (транексамова } \\
\text { кислота) } \\
\text { - Артроцентез } \\
\text { - Р.R.І.С.Е. } \\
\text { - Фізіотерапія, реабілітація }\end{array}$ \\
\hline
\end{tabular}

*P.R.I.С.Е.-терапія — комплекс допоміжних заходів у разі гострого крововиливу в суглоб, який включає захист травмованого суглоба від статико-динамічного навантаження, функціональний спокій та стиснення (компресія) для суглоба протягом > 24 год, аплікації льоду через вологий рушник на 10-15 хв через кожні 2 год та підвищене положення кінцівки.

Комплексний підхід до лікування пацієнтів з ІФГ у разі гострого гемартрозу полягає, по-перше, в якнайшвидшому введенні необхідної дози препарату із шунтуючим механізмом дії та, по-друге, терапія препаратами повинна тривати до моменту повного розсмоктування гемартрозу та зникнення проявів гемартриту. При цьому чим раніше від початку клінічних симптомів гемартрозу призначена відповідна терапія, тим кращим буде клінічний ефект від терапії. Рекомендована доза препаратів із шунтуючим механізмом дії при комплексній терапії у разі гострого гемартрозу у пацієнтів з ІФГ:

- aPCC: 50-100 MO/кг (максимальна добова доза -200 МО/кг) через кожні 12 год;

- rVIla: стартова разова доза 270 мкг/кг або 90 мкг/кг через кожні 2-3 год [9].

Важливо розуміти, що суглобові кровотечі не можуть самостійно розсмоктатися, особливо у разі великих та повторних кровотеч при гемофілії. Тому при менеджменті пацієнтів із гемофілією одним з ефективних та доцільних методів додаткового лікування в комплексній терапії у разі гемартрозу $\epsilon$ проведення артроцентезу - методу активної аспірації крові із суглоба при гемартрозі.

За підтримки ТОВ «Такеда Україна» VV-MEDMAT-38097

\section{Список використаної літератури/References:}

1. Ingerslev J., Freidman D., Gastineau D. et al. (1996) Major surgery in haemophilic patients with inhibitors using recombinant factor VIla. Haemostasis, 26(Suppl. 1): 118-123. doi: $10.1159 / 000217252$

2. Teitel J., Berntorp E., Collins P. et al. (2007) A systematic approach to controlling problem bleeds in patients with severe congenital haemophilia $A$ and high-titre inhibitors. Haemophilia, 13(3): 256-263. doi: 10.1111/j.1365-2516.2007.01449.x

3. Leissinger C.A. (1999) Use of prothrombin complex concentrates and activated prothrombin complex concentrates as prophylactic therapy in haemophilia patients with inhibitors. Haemophilia, 5(Suppl. 3): 25-32. doi: 10.1046/j.1365-2516.1999.00034.x

4. Leissinger C.A. (2004) Prevention of bleeds in hemophilia patients with inhibitors: emerging data and clinical direction. Am. J. Hematol., 77(2): 187-193. doi: 10.1002/ajh.20162

5. Scalone L., Mantovani L.G., Mannucci P.M. et al. (2006) Quality of life is associated to the orthopaedic status in haemophilic patients with inhibitors. Haemophilia, 12(2): 154-162. doi: $10.1111 /$ j.1365-2516.2006.01204.x

6. Rodriguez-Merchan E.C., Rocino A. (2004) Literature review of surgery management in inhibitor patients. Haemophilia, 10(Suppl. 2):22-29. doi: 10.1111/j.1365-2516.2004.00937.x

7. Averyanov E.V. (2015) Changes in the functional capacity of the extremities in patients with hemophilia with posthemorrhagic arthropathy. Hematology and blood transfusion: Collection of scientific works. iss. 38. pp. 345-346. (in Ukr.).

8. Pulles A.E., Mastbergen S.C., Schutgens R.E.G. et al. (2017) Pathophysiology of hemophilic arthropathy and potential targets for therapy. Pharmacol. Res., 115: 192-199. https://doi. org/10.1016/j.phrs.2016.11.032

9. Hanley J., McKernan A., Creagh M.D. et al. (2017) Guidelines for the management of acute joint bleeds and chronic synovitis in haemophilia: A United Kingdom Haemophilia Centre Doctors' Organisation (UKHCD0) guideline. Haemophilia, 23(4): 511-520. doi: 10.1111/ hae. 13201

\section{Information about the author:}

Averyanov Eugene V. — Candidate of Medical Sciences, Senior Research Officer, Head of the Department of the Surgical Hematology and Hemostasiology, State Institution «Institute of Hematology and Transfusiology of the NAMS of Ukraine», Kyiv, Ukraine.

\section{Address for correspondence:}

Eugene Averyanov

02000, Kyiv, Maxim Berlinsky str., 12

E-mail: evg.averyanov@gmail.com 
ТЕСТОВІ ЗАПИТАННЯ

(один або декілька правильних варіантів відповідей на кожне запитання)

1. Визначте ризик, пов'язаний з наявністю у пацієнтів з гемофілією інгібіторів:

$\square$ ризик прогресуючого захворювання суглобів

$\square$ ризик погіршення якості життя

$\square$ потреба у пристроях, що полегшують мобільність

$\square$ потреба в ортопедичній хірургії

$\square$ усі відповіді правильні

2. Який тип кровоточивості характерний для гемофілії?

$\square$ гематомний

$\square$ петехіально-плямистий

$\square$ змішаний (синцево-гематомний)

$\square$ васкулітно-пурпурний

$\square$ ангіоматозний

3. Визначте найбільш характерний клінічний симптом при гемофілії:

$\square$ гемартроз

$\square$ гідрартроз

$\square$ порушення ходи

$\square$ усі відповіді правильні

4. Визначте специфічне ураження суглоба, характерне для гемофілії:

$\square$ остеоартрит

$\square$ поліартрит

$\square$ гострий подагричний артрит

гемофілічна артропатія
5. Пусковим механізмом, що запускає каскад патологічних реакцій при гемофілічній артропатії, $\epsilon$ :

$\square$ окисний стрес

$\square$ виділення в синовіальну рідину заліза

$\square$ утворення в організмі ендогенних пірогенів

$\square$ усі відповіді правильні

6. Визначте ключові ланки патогенезу гемофілічної артропатії:

$\square$ гіпертрофія синовіальної оболонки

$\square$ гіперваскуляризація синовіальної оболонки

$\square$ дегенерація хряща

$\square$ резорбція кістки

7. Стратегія гемостатичної терапії пацієнтів із гемофілією представлена:

$\square$ замісною факторною гемостатичною терапією

$\square$ застосуванням препаратів із шунтуючим механізмом діï

$\square$ нефакторною терапією

$\square$ хірургічним втручанням

8. Стратегія гемостатичної терапії пацієнтів з ІФГ представлена застосуванням:

$\square$ препаратів із шунтуючим механізмом дії

$\square$ препаратів факторів згортання крові у стандартній дозі

$\square$ додаванням глюкокортикостероїдів до стандартної факторної терапії

$\square$ усі відповіді правильні

\section{Для отримання сертифіката дайте відповідь на тестові запитання в режимі on-line на сайті журналу www.umj.com.ua або надішліть ксерокопію сторінок з відповідями разом з контактною інформацією за адресою: 01001, Київ-1, a/c «В»-82, ТОВ «МОРІOН»}

ПІБ
Поштова адреса: індекс
область
район
місто
вулиця
будинок
квартира

